\title{
Peran Badan Pengawas Pemilu dalam Penanganan Tindak Pidana Pemilu di Kabupaten Simalungun
}

\section{The Role of the Election Supervisory Body in Handling Election Crimes in Simalungun Regency}

\author{
Michael Richard Siahaan'), Isnaini' ${ }^{1)} *$ \& Mirza Nasution') \\ 1) Program Magister Ilmu Hukum, Universitas Medan Area, Indonesia \\ 2) Program Magister Ilmu Hukum, Universitas Sumatera Utara, Indonesia \\ Diterima: 04 Agustus 2021; Direview: 06 Agustus 2021; Disetujui: 30 September 2021
}

*Coresponding Email: isnaini@staff.uma.ac.id

\begin{abstract}
Abstrak
Tulisan ini bertujuan untuk menganalisis peran Badan Pengawas Pemilu dan kendala yang dihadapi dalam penanganan tindak pidana pemilu di Kabupaten Simalungun. Metode penelitian yang digunakan adalah metode deskriptif, sedangkan teknik analisis data menggunakan deskriptif kualitatif. Berdasarkan hasil penelitian ini menunjukkan bahwa aturan hukum tentang peran Badan Pengawas Pemilu dalam penanganan tindak pidana pemilu dinyatakan dalam UU No. 7 tahun 2017 tentang Pemilihan Umum, Peraturan Badan Pengawas Pemilu No. 7 Tahun 2018 tentang Penanganan Temuan dan Laporan Pelanggaran Pemilihan Umum dan Peraturan Bawaslu No. 31 Tahun 2018 Tentang Sentra Penegakan Hukum Terpadu. Peran Badan Pengawas Pemilu dalam penanganan tindak pidana pemilu di Kabupaten Simalungun belum sepenuhnya dapat melaksanakan perannya dalam penanganan tindak pidana pemilu. Kendala yang dihadapi Badan Pengawas Pemilu dalam penanganan tindak pidana pemilu adalah: sering terjadi perbedaan persepsi dalam Sentra Gakkumdu, adanya kesempatan yang cukup besar untuk menghilangkan barang bukti, tersangka sering tidak kooperatif, serta kurangnya petugas Bawaslu padahal tugas yang harus dilaksanakan terutama pada saat penyelenggaraan pemilu relatif banyak.
\end{abstract}

Kata Kunci: Bawaslu; Pengawasan Pemilu; Tindak Pidana Pemilu.

\begin{abstract}
This paper aims to analyze the role of the Election Supervisory Body and the obstacles faced in handling election crimes in Simalungun Regency. The research method used is descriptive method, while the data analysis technique uses descriptive qualitative. Based on the results of this study indicate that the rule of law regarding the role of the Election Supervisory Body in handling election crimes is stated in Law no. 7 of 2017 concerning General Elections, Election Supervisory Body Regulation No. 7 of 2018 concerning Handling of Findings and Reports of General Election Violations and Bawaslu Regulation No. 31 of 2018 concerning the Integrated Law Enforcement Center. The role of the Election Supervisory Body in handling election crimes in Simalungun Regency has not been fully able to carry out its role in handling election crimes. The obstacles faced by the Election Supervisory Body in handling election crimes are: there are often differences in perceptions in the Gakkumdu Center, there is a large enough opportunity to eliminate evidence, suspects are often uncooperative, and the lack of Bawaslu officers even though the task must be carried out, especially during elections. relatively much.
\end{abstract}

Keywords: Bawaslu; Election Sopervisory; Election Crime.

How to Cite Siahaan, M.R., Isnaini \& Nasution, M. (2021). Peran Badan Pengawas Pemilu Dalam Penanganan Tindak Pidana Pemilu Di Kabupaten SimalungunPeran Badan Pengawas Pemilu Dalam Penanganan Tindak Pidana Pemilu Di Kabupaten Simalungun. Journal of Education, Humaniora and Social Sciences (JEHSS). 4 (2): 1209-1221 


\section{PENDAHULUAN}

Dalam Undang-undang Dasar Tahun 1945 dinyatakan bahwa Negara Kesatuan Republik Indonesia adalah negara hukum. Semua warga negara wajib menjunjung tinggi keberadaan hukum, dan semua warga negara mempunyai kedudukan yang sama di hadapan hukum. Dengan demikian, hukum ditempatkan pada posisi yang paling tinggi, dimana semua warga harus berperilaku hingga batas-batas yang diijinkan menurut hukum. Penerapan negara hukum Indonesia dalam kehidupan bermasyarakat bertujuan mewujudkan tata kehidupan bangsa guna melindungi segenap bangsa Indonesia dan seluruh tumpah darah Indonesia dan untuk memajukan kesejahteraan umum, mencerdaskan kehidupan bangsa, ikut melaksanakan ketertiban dunia yang berdasarkan kemerdekaan, perdamaian abadi dan keadilan sosial.

Selanjutnya dalam UUD Tahun 1945 juga dinyatakan bahwa Negara Indonesia menganut paham demokrasi yang artinya kekuasaan atau kedaulatan berada di tangan rakyat. Hal ini tercermin dalam pasal 1 ayat (2) UUD 1945 yang menentukan bahwa kedaulatan berada di tangan rakyat dan dilaksanakan menurut Undang-Undang Dasar. Adapun yang dimaksud kedaulatan rakyat di tangan rakyat adalah segala bentuk penyelenggaraan yang berhubungan dengan kesejahteraan rakyat, harus dipertanggungjawabkan kepada rakyat. Kedaulatan rakyat juga berarti pemerintahan dari rakyat, oleh rakyat, dan untuk rakyat. Pemerintahan dari rakyat berarti mereka yang duduk sebagai penyelenggara pemerintahan terdiri dari rakyat itu sendiri dan mendapat dukungan rakyat. Pemerintahan oleh rakyat berarti pemerintahan dilakukan dan diselenggarakan oleh rakyat baik melalui demokrasi langsung maupun demokrasi perwakilan. Dalam negara yang menganut demokrasi, keterlibatan rakyat membentuk pemerintahan sebagai wujud pelaksanaan kedaulatan rakyat adalah melalui pemilihan umum.

Pemilihan umum (pemilu) merupakan prosedur demokrasi untuk memilih pemimpin, dimana terdapat keyakinan bahwa mekanisme pergantian kekuasaan (suksesi) yang paling aman, sehingga sering dinyatakan bahwa pemilu merupakan pilar utama dari sebuah demokrasi. Pelaksanaan pemilihan umum sangat penting dilakukan karena berfungsi memberi legitimasi atas kekuasaan yang ada bagi suatu rezim, sebagai pengakuan dan dukungan atas sahnya suatu kekuasaan. Dalam pemilu, aspirasi rakyat akan disampaikan, dan rakyat akan menilai para kontestan pemilu yang menawarkan visi, misi, sehingga mereka akan tahu ke mana arah perjalanan negaranya. Sedemikian pentingnya pelaksanaan pemilu sehingga proses pemilu harus diselenggarakan sesuai dengan norma-norma hukum yang berlaku, serta dilaksanakan sesuai dengan asas-asas pemilihan umum, yaitu langsung, umum, bebas, rahasia, jujur, dan adil.

Pelaksanaan pemilihan umum telah diatur dalam Undang-Undang Nomor 7 Tahun 2017 Tentang Pemilihan Umum (UU Pemilu). Artinya pemilu akan berjalan dengan baik sesuai dengan norma demokrasi jika semua pihak yang terlibat dalam pemilu benar-benar mematuhi semua aturan hukum yang terdapat dalam undang-undang tersebut. Tetapi pada kenyataannya pada setiap pelaksanaan pemilu masih banyak ditemukan pelanggaran, baik pelanggaran pada masa kampanye maupun pada saat pelaksanaan pemilihan umum. Pelanggaran yang terjadi dapat berupa pelanggaran kode etik penyelenggara pemilu, pelanggaran administrasi, serta dugaan tindak pidana pemilu.

Salah satu pelanggaran pemilu adalah tindak pidana pemilu. Jenis tindak pidana pemilu ini yaitu memberikan keterangan yang tidak benar dalam pengisian data diri daftar pemilih, kepala desa melakukan tindakan menguntungkan atau merugikan peserta pemilu, mengganggu jalannya kampanye, melakukan kampanye diluar jadwal yang telah ditetapkan, pelaksana kampanye melakukan pelanggaran kampanye, memberikan keterangan tidak benar dalam laporan dana kampanye pemilu, menyebabkan orang lain kehilangan hak pilihnya, menetapkan jumlah surat suara yang dicetak melebihi jumlah yang ditentukan, serta memberikan suaranya lebih dari satu kali. Semua jenis pelanggaran tersebut dinyatakan sebagai tindak pidana pemilu sebagaimana telah diatur dalam undang-undang pemilu.

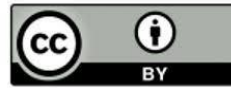


Beberapa jenis tindak pidana pemilu yang terjadi di Kabupaten Simalungun adalah sebagai berikut: Badan Pengawas Pemilihan Umum (Bawaslu) Kabupaten Simalungun "membidik" dugaan keterlibatan oknum pejabat pemerintahan termasuk kepala desa (kades) pada pemilu legislatif, calon Presiden dan calon Wakil Presiden 2019. Komisioner Bawaslu Simalungun Divisi Hukum, Data dan Informasi, Michael Siahaan mengatakan, pihaknya mengakui banyak menerima informasi dari masyarakat terkait indikasi adanya mobilisasi atau pengarahan suara oleh oknum pejabat dan Kades di Pemkab Simalungun untuk calon legislatif tertentu khususnya kabupaten dan provinsi serta pasangan calon presiden dan wakil presiden Pemilu 2019. Bawaslu Simalungun gelar Rapat Koordinasi (Rakor) Sentra Penegakan hukum terpadu (Gakkumdu) dalam rangka Penanganan Pelanggaran Pemilu tahun 2019, di Hotel Sapadia, Kota Siantar, pada tanggal 1 April 2019. Menurut Kasat Reskrim Polres Simalungun, AKP Ruzi Gusman SH, SIK, M.Si sebagai narasumber menyampaikan adanya temuan atau laporan, penanganan harus melalui beberapa langkah, kemudian ditentukan apakah pelanggaran pemilunya berupa pelanggaran kode etik, administratif atau pelanggaran tindak pidana, harus memenuhi syarat formil dan materil. Himpunan Mahasiswa Islam (HMI) Cabang Pematangsiantar-Simalungun, melaporkan Camat Gunung Malela Andi S Pasaribu kepada Bawaslu Simalungun. Ketua HMI Jhoni Arifin Tarigan kepada Mistar mengatakan, pengaduan terhadap Camat tersebut karena HMI menduga Camat Andi Pasaribu telah melakukan kegiatan mempengaruhi pilihan masyarakat, untuk mendukung salah satu pasangan calon kepala daerah, pada saat Camat tersebut sedang melaksanakan tugas sebagai ASN. MPC PP Simalungun antarkan laporan ke Bawaslu yang langsung diterima oleh Jasniar Sitanggang selaku staf Bawaslu bidang pelanggaran. Laporan yang diterima tim Sekretariat MPC PP Simalungun berasal dari beberapa kecamatan. Laporan tersebut pun disertai bukti foto dan video dan waktu peristiwa. Salah satu temuan yang telah dilaporkan ke Bawaslu Simalungun adalah Pangulu Nagori Naga Sopha Kecamatan Bandar Huluan Kabupaten Simalungun atas adanya indikasi ketidaknetralan pangulu dan perangkatnya dalam proses Pilkada, karena terlibat dalam mendukung dan memenangkan salah satu paslon.

Penanganan tindak pidana pemilu merupakan kewenangan dari Bawaslu sesuai dengan tingkatannya, yaitu Bawaslu RI, Provinsi, dan Kabupaten atau Kota. Pada pasal 101 huruf a UU Pemilu dinyatakan bahwa Bawaslu Kabupaten atau Kota bertugas melakukan pencegahan dan penindakan terhadap pelanggaran pemilu dan sengketa proses pemilu. Selanjutya pada pasal 103 huruf a dinyatakan bahwa Bawaslu Kabupaten atau Kota berwewenang menerima dan menindaklanjuti laporan yang berkaitan dengan dugaan pelanggaran terhadap pelaksanaan peraturan perundang-undangan yang mengatur mengenai pemilu, baik pelanggaran kode etik, administrasi maupun tindak pidana, dimana Bawaslu harus segera bersidang (sidang pleno) untuk menentukan jenis pelanggaran yang terjadi.

Bawaslu berkewajiban melaporkan adanya tindak pidana pemilu kepada polisi paling lama 24 jam setelah Bawaslu dan Panwaslu menyatakan bahwa perbuatan atau tindakan yang diduga merupakan tindak pidana pemilu. Pada tahap selanjutnya, penyidik kepolisian melakukan proses hukum dengan melakukan penyelidikan dan penyidikan hingga pelimbahan (penyerahan) berkasnya ke penuntut umum.

Dengan demikian jelas bahwa satu-satunya fungsi yang berwewenang membuat laporan pelanggaran tindak pidana pemilu kepada kepolisian adalah Bawaslu atau Panwaslu. Hal ini menjadi suatu kekhususan dalam penanganan tindak pidana pemilu dari tindak pidana umum lainnya, yaitu adanya peran Bawaslu sebagai pintu gerbang laporan terjadinya pelanggaran dan kejahatan dalam pemilu. Apabila masyarakat ada yang mengetahui tentang pelanggaran pemilu, maka pihak yang menerima laporan pertama adalah badan Pengawas Pemilu (Bawaslu) RI, Bawaslu Provinsi, Panwaslu Kabupaten atau Kota, Panwaslu Kecamatan, Pengawas Pemilu Lapangan dan Pengawas Pemilu Luar Negeri apabila terjadi di luar negeri. Laporan tersebut tentunya harus dilengkapi dengan bukti-bukti yang akurat sesuai dengan pelanggaran atau kejahatan yang terjadi, artinya dalam hal adanya laporan pelanggaran pidana pemilu, maka Bawaslu akan terlebih dahulu meneliti laporan tentang pelanggaran atau kejahatan pemilumang wwit http://mahesainstitute.web.id/ojs2/index.php/jehss 1211

․․…com

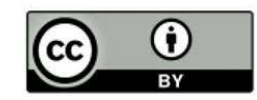

This work is licensed under a Creative Commons Attribution 4. 
disertai dengan adanya koordinasi dengan kepolisian dan kejaksaan dalam Gakkumdu sebelum laporan pelanggaran tersebut disampaikan kepada kepolisian. Tujuan dalam penelitian ini adalah untuk menganalisis peran Bawaslu dan kendala yang dihadapi Bawaslu dalam penanganan tindak pidana pemilu di Kabupaten Simalungun.

\section{METODE PENELITIAN}

Istilah metode penelitian terdiri atas dua kata, yaitu kata metode dan kata penelitian. Kata metode berasal dari bahasa Yunani yaitu methodos yang berarti "cara atau menuju suatu jalan". Metode merupakan "kegiatan ilmiah yang berkaitan dengan suatu cara kerja (sistematis) untuk memahami suatu objek atau objek penelitian, sebagai upaya untuk menemukan jawaban yang dapat dipertanggungjawabkan secara ilmiah dan termasuk keabsahannya" (Ruslan, 2003).

Penelitian adalah sarana pokok dalam pengembangan ilmu pengetahuan dan teknologi yang bertujuan untuk menggungkapkan kebenaran secara sistematis, metodologis dan konsisten. Metode penelitian adalah usaha untuk menemukan, mengembangkan dan menguji kebenaran suatu pengetahuan (Hadi, 2020). Metode penelitian hukum merupakan suatu cara yang teratur (sistematis) dalam melakukan sebuah penelitian (Muhammad, 2004).

Jenis penelitian ini adalah penelitian yuridis normatif yang didukung oleh data kepustakaan, hal ini dikarenakan penelitian ini merupakan penelitian hukum doktriner yang disebut juga penelitian kepustakaan atau studi dokumen yang dilakukan atau ditunjukkan pada peraturan yang tertulis atau bahan hukum yang lain (Waluyo, 1993). Penelitian normatif merupakan penelitian ilmiah untuk menemukan kebenaran berdasarkan logika keilmuan hukum dari sisi normatifnya (Johni, 2005). Penelitian normatif sering kali disebut dengan penelitian doctrinal, yaitu penelitian yang objek kajiannya adalah dokumen perundangundangan dan bahan kepustakaan (Abdurrahman,2005).

Penelitian ini bersifat deskriptif analisis, termasuk dalam lingkup penelitian yang menggunakan atau menggambarkan penerapan suatu peraturan hukum dan pelaksanaannya dalam masyarakat (Johni, 2005).

Metode penelitian sangat penting dalam menganalisa sebuah penelitian. Metode penelitian yang digunakan dalam penelitian ini adalah pendekatan pustaka dengan metode pendekatan kasus, yaitu berdasarkan kasus tindak pidana pemilihan umum yang terjadi di Bawaslu Kabupaten Simalungun; Metode pendekatan perundang-undangan (statute approach) yaitu dilakukan dengan menelaah ketentuan perundang-undangan yang berlaku dalam menjawab permasalahan penelitian yaitu kitab Undang-Undang Hukum Pidana (KUHP), Undang-Undang No. 7 Tahun 2017 tentang Pemilihan Umum.

Sumber data dalam penelitian ini adalah data sekunder. Untuk menghimpun data sekunder, maka dibutuhkan bahan pustaka yang merupakan data dasar yang terdiri dari bahan hukum primer, bahan hukum sekunder dan bahan hukum tersier (Soemitro, 1990). Bahan hukum primer, Yaitu bahan-bahan yang berisikan peraturan dan Perundang-Undang yang mengikat, yang terdiri dari peraturan Perundang-Undangan dan peraturan pelaksanaannya, di antaranya adalah Norma atau kaidah dasar, Undang-Undang Dasar Negara Republik Indonesia, Peraturan Perundang-undangan, kitab Undang-Undang Hukum Pidana (KUHP), Undang-Undang No. 7 Tahun 2017 tentang Pemilihan Umum.

Data sekunder diperoleh dari penelitian kepustakaan dan data primer yang diperoleh dari penelitian lapangan dalam bentuk wawancara untuk melengkapi data-data yang diperoleh dari penelitian pustaka. Kemudian dikumpulkan dan dikelompokan sesuai dengan data sejenis, serta disusun secara berurutan dan sistematis untuk selanjutnya dianalisis secara kualitatif dengan metode deduktif (Soemitro, 1990).

Bahan hukum tersier, merupakan bahan hukum yang memberikan petunjuk maupun penjelasan terhadap bahan hukum primer dan bahan hukum sekunder (Soekanto and Mamudji, 1995). Berupa kamus, ensiklopedia, dan sebagainya yang relevan dengan penelitian. Data

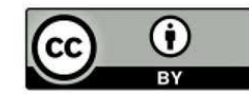


primer sebagai data pendukung diperoleh dari hasil wawancara, berupa kata-kata dan tindakan yang berhubungan dengan persepsi atau opini.

Teknik yang dipergunakan untuk pengumpulan data atau bahan hukum dalam penelitian ini adalah: penelitian kepustakaan (library research), studi kepustakaan ini adalah mencari bahan hukum atau data dengan mengkaji dokumen hukum, berupa konsep-konsep, teori, pendapat atau penemuan-penemuan yang berhubungan erat dengan pokok permasalahan dalam berbagai literatur buku-buku hukum, jurnal hukum dan ketentuan perundang-undangan. Dengan demikian dapat dikumpulkan data sekunder sebagai kerangka kerja teoritis. Penelitian lapangan (field research), dilakukan dengan cara peninjauan langsung terhadap objek penelitian untuk memperoleh data-data yang dibutuhkan. Penelitian lapangan dilakukan dengan mengadakan penelitian langsung melalui wawancara dengan pihak-pihak yang berwenang di Kepolisian Daerah Provinsi Sumatera Utara.

\section{HASIL DAN PEMBAHASAN}

Peraturan Bawaslu No. 7 Tahun 2018 tentang Penanganan Temuan dan Laporan Pelanggaran Pemilihan Umum dan Peraturan Bawaslu No. 31 Tahun 2018 Tentang Sentra Penegakan Hukum Terpadu. Dalam Peraturan Bawaslu Nomor 7 Tahun 2018 tentang Penanganan Temuan dan Laporan Pelanggaran Pemilihan Umum. Pada Bab I bagian Ketentuan Umum Pasal 1 angka 25 PerBawaslu ini menyebutkan, "temuan Pelanggaran yang selanjutnya disebut Temuan adalah hasil pengawasan Bawaslu, Bawaslu Provinsi dan/atau Bawaslu Kabupaten/Kota, Panwaslu Kecamatan, Panwaslu Kelurahan/ Desa, Panwaslu LN, dan/ atau Pengawas TPS pada setiap tahapan Penyelenggaraan Pemilu yang mengandung dugaan pelanggaran".

Selanjutnya Pasal 1 angka 26 PerBawaslu No. 7 Tahun 2018 juga mengatur definisi dari laporan. Laporan menurut PerBawaslu adalah laporan langsung Warga Negara Indonesia yang mempunyai hak pilih, Peserta Pemilu, atau pemantau Pemilu kepada Bawaslu dan/atau Bawaslu Kabupaten/Kota, Panwaslu Kecamatan, Panwaslu Kelurahan/Desa, Panwaslu LN, dan/atau Pengawas TPS pada setiap tahapan Penyelenggaraan Pemilu.

Atas dasar itu, sumber informasi dari laporan adalah pihak eksternal di luar Bawaslu secara institusi. Orang yang berhak melakukan pelaporan terhadap adanya dugaan pelanggaran pemilu menurut PerBawaslu terdiri dari warga negara Indonesia yang mempunyai hak pilih, kemudian para pemantau pemilu, ataupun peserta pemilu. Pada tahap menyampaikan laporan, para pelapor sebagaimana yang telah disebutkan, dapat didampingi oleh kuasa yang telah menerima surat kuasa dari pelapor. Keduanya adalah laporan dan temuan. Untuk menindaklanjuti atau tidak menindaklanjuti temuan maupun laporan dugaan pelanggaran, paling lama 7 hari kerja setelah diterima dan diregistrasi.

Pasal 17 PerBawaslu No. 7 Tahun 2018 mengatur durasi penanganan temuan maupun laporan dugaan pelanggaran pemilu. Bawaslu pada setiap tahapan dalam memutuskan untuk menindaklanjuti atau tidak menindaklanjuti temuan maupun laporan dugaan pelanggaran, paling lama 7 hari kerja setelah diterima dan diregistrasi. Apabila terhadap temuan maupun laporan tersebut, dibutuhkan adanya keterangan tambahan mengenai tindak lanjut, maka terhadap keterangan tambahan dan kajiannya diberikan waktu paling lama 14 hari kerja setelah diterima dan diregistrasi.

Selanjutnya dalam proses pengkajian terhadap temuan maupun laporan dugaan pelanggaran, Bawaslu di semua tingkatan dapat melakukan klarifikasi terhadap pelapor, terlapor, maupun pihak yang diduga sebagai pelaku pelanggaran, saksi, atau ahli untuk didengar keterangannya. Keterangan tersebut dituangkan dalam berita acara klarifikasi sebagaimana formulir berita acara klarifikasi.

Pasal 18 angka 3 PerBawaslu No. 7 Tahun 2018 menyatakan Klarifikasi dan/atau permintaan keterangan dilakukan oleh Bawaslu, Bawaslu Provinsi, Bawaslu Kabupaten/Kota, Panwaslu Kecamatan, dan Panwaslu LN dan/atau tim klarifikasi yang ditunjuk.

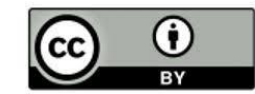


Di dalam Pasal 1 Peraturan BadanPengawas Pemilihan Umum (Bawaslu) Republik Indonesia Nomor 31 Tahun2018 Tentang Sentra Penegakan Hukum Terpadu, Gakkumdu adalah pusataktivitas penegakan hukum tindak pidana Pemilu yang terdiri dari unsurBadan Pengawas Pemilihan Umum, Badan Pengawas Pemilihan UmumProvinsi, dan/atau Badan Pengawas Pemilihan Umum Kabupaten/Kota,Kepolisian Negara Republik Indonesia, Kepolisian Daerah, dan/atauKepolisian Resor, dan Kejaksaan Agung Republik Indonesia, KejaksaanTinggi dan/atau Kejaksaan Negeri.

Fungsi Sentra Gakkumdu adalah sebagai forum koordinasi dalam proses penanganan setiap pelanggaran tindak pidana pemilu, pelaksanaan pola tindak pidana pemilu itu sendiri, pusat data, peningkatan kompetensi, monitoring evaluasi. Sementara mengenai pola penanganan tidak pidana pemilu telah dirinci dalam Standar Operasional dan Prosedur (SOP) tentang Tindak Pidana Pemilu pada Sentra Gakkumdu dimana tertuang dalam PerBawaslu Nomor 31 Tahun 2018. Hal itu diharapkan dapat menciptakan sistem pemilihan umum yang baik dan efektif.

Menurut SOP Sentra Gakkumdu, penanganan tindak pidana pemilu dilaksanakan melalui 3 (tiga) tahap yaitu: 1) Penerimaan, pengkajian dan penyampaian laporan/temuan dugaan tindak pidana pemilu kepada Pengawas Pemilu; dalam tahap ini Pengawas Pemilu berwenang menerima laporan atau temuan dugaan pelanggaran pemilu yang diduga mengandung unsur tindak pidana pemilu, selanjutnya dugaan pelanggaran itu dituangkan dalam Formulir Pengaduan. Setelah menerima laporan atau temuan adanya dugaan tindak pidana pemilu, Pengawas Pemilu segera berkoordinasi dengan Sentra Gakkumdu dan menyampaikan laporan atau temuan tersebut kepada Sentra Gakkumdu dalam jangka waktu paling lama 24 Jam sejak diterimanya laporan atau temuan. 2) Tindak lanjut Sentra Gakkumdu terhadap laporan atau temuan dugaan tindak pidana pemilu; dalam tahap ini dilakukan pembahasan oleh Sentra Gakkumdu dengan dipimpin oleh anggota Sentra Gakkumdu yang berasal dari unsure Pengawas Pemilu. 3) Tindak lanjut Pengawas Pemilu terhadap rekomendasi Sentra Gakkumdu, Dalam tahap ini disusun rekomendasi Sentra Gakkumdu, yang menentukan apakah suatu laporan atau temuan merupakan dugaan tindak pidana pemilu atau bukan, atau apakah laporan atau temuan tersebut perlu dilengkapi dengan syarat formil atau syarat materiil.

Beberapa laporan dari Bawaslu belum dilengkapi dengan alat bukti yang mendukung perbuatan pidana yang dilaporkan sebagaimana diatur dalam pasal 184 UU No 8 Tahun 198 tentang KUHAP. Hal ini disebabkan oleh kurangnya pemahaman aspek hukum terhadap perbuatan pelanggaran atau kejahatan, khususnya tentang alat bukti yang harus dipenuhi, yaitu minimal 2 alat bukti yang sah sebagai syarat utama agar perkara tersebut dapat diproses. Kadangkala terjadi salah persepsi antara Bawaslu dan Penyidik, seolah-olah penyidik polri tidak menindaklanjuti perkara tersebut. Hal ini apabila dibiarkan tanpa ada solusi, tentu akan menjadi kontraproduktif terhadap upaya penegakan hukum tindak pidana pemilu dimasa yang akan datang. Ada beberapa solusi yang dapat dilakukan, antara lain diselenggarakan pelatihan bersama atau terpadu dari aparat yang terlibat dalam Gakkumdu (penegakan hukum terpadu) untuk penanganan tindak pidana pemilu, sehingga Nota Kesepahaman tentang Sentra Penegakan Hukum Terpadu (Gakkumdu) tindak pidana Pemilu Legislatif yang pernah dibuat bukan hanya berlaku pada tataran pimpinan. Pelatihan terpadu tersebut sangat penting untuk meningkatkan kemampuan dan koordinasi antara instansi sehingga dapat meminimalisir terjadinya perbedaan persepsi.

Peraturan perundang-undangan yang kedudukannya berada di bawah undang-undang seperti Peraturan Bawaslu No. 31Tahun 2018 tidak boleh bertentangan dengan dan/atau harus bersumber dan berdasarpada UU No. 7 Tahun 2017, sebagaimana teori jenjang norma atau stufentheorie dariHans Kelsen dan teori jenjang norma hukum atau die theorie vom stufenordnung der rechtsnormen dari Hans Nawiasky yang menyebutkan bahwa suatu norma itu berlaku,bersumber, dan berdasar pada norma yang di atasnya. Demikian pula halnya dengan UU No. 8 Tahun 1981 tentang Hukum Acara Pidana yang bersifat umum untuk semua tindak

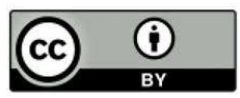


pidana, hal-hal yang diatur didalamnya terkait dengan penyelidikan, penyidikan,penuntutan, dan pemeriksaan tindak pidana di sidang pengadilan menjadi tidak berlaku atau terkesampingkan oleh ketentuan yang diatur dalam UU No. 7 Tahun 2017 yang mengatur secara khusus tentang tindak pidana Pemilu dan tata cara penanganannya.

\section{Peran Bawaslu dalam Penanganan Tindak Pidana Pemilu di Kabupaten Simalungun}

Peran Bawaslu tentang Norma. Dalam setiap melakukan perannya, setiap lembaga harus berpedoman pada norma yang telah ditetapkan. Norma merupakan suatu peraturan yang merupakan petunjuk atau juga pedoman dalam perilaku yang benar dan pantas dalam melaksanakan perannya saat melakukan pekerjaan dan berinteraksi dengan orang lain. Peranan meliputi norma-norma yang dihubungkan dengan posisi seseorang atau kelompok (organisasi) dalam masyarakat. Peranan dalam arti ini merupakan rangkaian peraturanperaturan yang membimbing seseorang dalam kehidupan masyarakat. Norma merupakan suatu peraturan yang merupakan petunjuk atau juga pedoman dalam perilaku yang benar dan pantas dalam melaksanakan perannya saat melakukan pekerjaan dan berinteraksi dengan orang lain. Norma ditetapkan pada dasarnya agar dapat mengubah atau membatasi atau mengarahkan perilaku individu untuk mencapai tujuan bersama yang diharapkan dapat diwujudkan di tengah masyarakat.

Peran Bawaslu dalam penyelenggaraan pemilu juga diatur dalam norma hukum, maupun norma dalam bentuk budaya organisasi dan kontrolsosial masyarakat. UU Pemilu menjelaskan secara rinci tentang peran Bawaslu dalam penanganan tindak pidana pemilu, dimana Bawaslu merupakan satu-satunya pintu masuk bagi penanganan tindak pidana pemilu. Disamping itu, peran Bawaslu juga dipengaruhi oleh budaya organisasi yang dianut oleh seluruh jajatan Bawaslu, serta juga memperhatikan adanya kontrolsosial dari masyarakat umum yang selalu memperhatikan dengan seksama pelaksanaan pemilu, sebagaimana akan dijelaskan di bawah ini.

UU No. 7 Tahun 2017. Adapun dasar hukum atas peran Bawaslu dalam pemilu diatur dalam UU No. 7 Tahun 2017 tentang Pemilihan Umum. Dalam UU tersebut dijelaskan bahwa penanganan pelanggaran pemilu harus melalui Bawaslu sesuai dengan laporan dari masyarakat. UU Pemilu mengamanatkan Bawaslu memiliki peran penting dalam penanganan tindak pidana pemilu, karena satu-satunya fungsi yang berwewenang membuat laporan pelanggaran tindak pidana pemilu kepada kepolisian adalah Bawaslu atau panwaslu. Hal ini menjadi suatu kekhususan dalam penanganan tindak pidana pemilu dari tindak pidana umum lainnya, yaitu adanya peran Bawaslu sebagai pintu gerbang laporan terjadinya pelanggaran dan kejahatan dalam pemilu legislatif. Apabila masyarakat ada yang mengetahui tentang pelanggaran pemilu, maka pihak yang menerima laporan pertama adalah badan Pengawas Pemilu (Bawaslu) RI, Bawaslu Provinsi, Panwaslu Kabupaten/Kota, Panwaslu Kecamatan, Pengawas Pemilu Lapangan dan Pengawas Pemilu Luar Negeri apabila terjadi di luar negeri. Laporan tersebut tentunya harus dilengkapi dengan bukti-bukti yang akurat sesuai dengan pelanggaran atau kejahatan yang terjadi. Artinya dalam hal adanya laporan pelanggaran pidana pemilu, maka dengan demikian peran Bawaslu tersebut adalah meneliti laporan tentang pelanggaran atau kejahatan pemilu yang disertai dengan adanya koordinasi dengan kepolisian dan kejaksaan dalam Gakkumdu sebelum laporan pelanggaran tersebut disampaikan kepada kepolisian.

Tupoksi Bawaslu. Tupoksi adalah sasaran utama atau pekerjaan yang dibebankan kepada organisasi untuk dicapai dan dilakukan. Tupoksi mengarahkan setiap kegiatan organisasi kepada tujuan yang telah ditetapkan, sehingga dapat dikatakan berlaku sebagai norma bagi organisasi yang bersangkutan. Peran Bawaslu juga diatur dalam tugas pokok dan fungsinya. Adapun tugas Bawaslu pada pokoknya adalah melakukan pencegahan dan penindakan terhadap pelanggaran pemilu dan sengketa proses pemilu, serta melakukan pengawasan terhadap penyelenggaraan pemilu. Bawaslu dalam penanganan tindak pidana pemilu juga berpedoman pada tupoksi. Dengan demikian berdasarkan tupoksinya, Bawaslu berperan mencegah terjadinya pelanggaran dengan cara melakukan pengawasan terhadap seluruh preses whttp://mahesainstitute.web.id/ojs2/index.php/jehss

mahesainstitut@gmail.com 1215

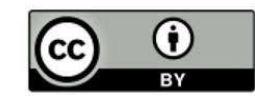

This work is licensed under a Creative Commons Attribution 4. 
penyelenggaraan pemilu. Pengawasan tidak terbatas hanya pada penyelenggaran pemilu yaitu KPU tetapi juga melakukan pengawasan terhadap kegiatan para konstentan pemilu, serta juga menindaklanjuti setiap pelanggaran yang dilakukan selama pelaksanaan pemilu oleh masyarakat.

Norma Budaya Organisasi Bawaslu. Setiap organisasi juga memiliki budaya yang menjadi ciri khas organisasi mereka masing-masing, yang disebut sebagai budaya organisasi. Budaya organisasi adalah sistem nilai yang dianut oleh anggota organisasi yang kemudian mempengaruhi cara mereka dalam bekerja, berperilaku dan beraktivitas. Bawaslu juga memiliki budaya yang menjadi ciri khas organisasi. Budaya tersebut terlihat dari adanya pemahaman bersama terhadap pentingnya pelaksanaan setiap pekerjaan secara disiplin dan berhasil. Bawaslu telah memiliki budaya organisasi sebagai bagian dari norma bersama yang harus dipatuhi pegawai. Tetapi fakta menunjukkan bahwa budaya organisasi yang dimaksud sebenarnya tidak begitu kuat mengikat perilaku semua pegawai. Justru pegawai menjadi kurang komitmen terhadap pekerjaannya jika terdapat urusan pribadi atau urusan keluarga yang dianggapnya lebih penting. Disamping itu terdapat juga budaya yang berkembang berupa tingginya persaingan diantara sesama pegawai sehingga mengarah pada adanya persaingan yang tidak sehat, sehingga mendorong pegawai untuk lebih menonjolkan sifat egoisme terhadap kepentingan masing-masing. Hal ini menyebabkan pegawai menjadi lebih mengutamakan pendekatan pribadi terhadap atasan dibanding peningkatan prestasi kerjanya. Dengan demikian peran Bawaslu kurang begitu kuat dalam budaya organisasi.

Norma Kontrol Sosial dari Masyarakat. Dalam hubungan pemerintah dengan masyarakat, terdapat hubungan timbal balik yang mengikat sangat kuat, sehingga terbentuk kontrolsosial sebagai norma. Norma yang cukup penting peranannya di tengah masyarakat dalam mengatur perilaku adalah kontrolsosial, yang dilakukan oleh anggota masyarakat terhadap anggota masyarakat lainnya dan juga antara masyarakat dengan pemerintah setempat. Kontrol sosial telah lama diakui dapat membentuk dan mengarahkan perilaku individu ataupun organisasi untuk tidak menyimpang. Kontrol sosial juga telah menjadi norma yang terbentuk yang berfungsi mengontrol peran Bawaslu. Dalam hal ini masyarakat akan memberikan saran bagi perbaikan penanganan tugas Bawaslu. Masyarakat juga dapat memberi kritik jika terdapat petugas Bawaslu yang tidak netral dalam melakukan pengawasan, sehingga menjadi bahan korektif bagi Bawaslu. Tugas Bawaslu harus dilaksanakan dengan menjunjung tinggi netralitas, dalam arti tidak boleh memihak kepada salah satu pihak yang mengikuti pemilu sebagai peserta.

Peran Bawaslu Dalam Organisasi. Soerjono Soekanto juga mengungkapkan peranan sebagai suatu konsep perihal apa yang dilakukan oleh individu dalam masyarakat sebagai organisasi. Bawaslu sebagai organisasi juga memberikan peranan penting dalam penyelenggaraan pemilu, yang terdiri dari menerima laporan masyarakat, melakukan pemeriksaan terhadap laporan, menetapkan adanya tidaknya pelanggaran tindak pidana.

Berperan Menerima Laporan Tindak Pidana Pemilu. Seperti telah dijelaskan sebelumnya bahwa Bawaslu menerima laporan dugaan tindak pidana pemilu dari masyarakat. Masyarakat yang melihat atau mengetahui adanya pelanggaran pidana pemilu dapat melaporkannya ke Bawaslu, kemudian Bawaslu meneliti laporan yang diterima dari masyarakat, dimana laporan tersebut tentu harus dilengkapi dengan adanya bukti-bukti yang kuat. Masyarakat perlu membuat laporan yang jelas dan lengkap agar dapat membantu Bawaslu dalam pemeriksaan perkara, karena waktu Bawaslu menetapkan adanya tindak pidana dalam pelanggaran yang dilaporkan adalah sangat terbatas.Tetapi disamping itu, Bawaslu juga harus selalu berada dalam kondisi siap menerima dan menindaklanjuti laporan dari masyaraakt, karena bagaimana pun Bawaslu juga mempunyai banyak tugas-tugas yang lain selama penyelenggaraan pemilu sebagaimana diamanatkan oleh undang-undang.

Pada dasarnya Bawaslu Kabupaten Simalungun selalu berada dalam kondisi siap untuk menerima laporan pelanggaran pemilu dari masyarakat. Namun demikian kelancaran dari

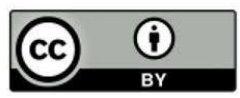


proses pelaporan tersebut masih tergantung pada akurasi dan kelengkapan laporan yang disampaikan masyarakat. Dengan demikian peran Bawaslu tersebut jika terdapat banyak kekurangan dalam laporan masyarkat tentu Bawaslu menjadi lebih lama dalam penangani setiap laporan sehingga dapat mengganggu kelancaran pelaksanaan tugas. Disamping itu, jumlah petugas Bawaslu juga cukup terbatas padahal tugas-tugas selama penyelenggaraan pemilu sangat banyak, sehingga harus benar-benar diperhatikan dalam pembagian tugas dan pelaksanaan tugas harian. Artinya jika terdapat tugas lain yang lebih mendesak maka terdapat kemungkinan Bawaslu dalam keadaan tidak siap menerima laporan. Namun demikian Bawaslu tetap berupaya secara maksimal agar setiap laporan dapat diterima dengan baik sesuai dengan aturan hukum yang berlaku.

Jenis tindak pidana yang terjadi pada saat pemilihan umum sangat beragam, seperti pelanggaran masa kampanye oleh peserta pemilu, pelanggaran pemalsuan identittas atau persyaratan yang dilakukan oleh calon. Sedangkan laporan yang paling banyak adalah penyebaran berita bohong (hoax) yang dilakukan melalui jejaring sosial dengan tujuan untuk mengurangi keterpilihan calon lain dan politik uang yang banyak terjadi di tengah-tengah masyarakat untuk menarik suara pemilih. Pelaku atau tersangka dalam tindak pidana tersebut dapat berasal dari peserta atau konstentan yang mencalonkan diri, dan juga dapat berasal dari masyarakat umum yang merupakan simpatisan dari calon. Namun demikian pelanggaran juga dapat terjadi dengan pelaku penyelenggaran pemilu dan pihak lain yang seharusnya mengambil posisi neteral sebagaimana diatur dalam undang-undang.

Laporan dari masyarakat sering hanya menyertakan isi minimal dari laporan, yaitu nama dan alamat pelapor, pihak terlapor, waktu dan tempat kejadian perkara, serta uraian kejadian. Menurut hasil wawancara bahwa laporan yang demikian tergolong sangat minimal dalam arti kurang memadai untuk dapat mempermudah tugas Bawaslu dalam melakukan tindak lanjut atas laporan. Kepolisian berharap bahwa dalam laporan tersebut dapat disertai dengan adanya barang bukti yang berkaitan dengan tindak pidana, atau setidaknya terdapat petunjuk awal mengenai alat bukti yang dapat digunakan, terutama petunjuk mengenai dimana atau bagaimana memperolah alat bukti yang bersangkutan. Bawaslu sering menghadapi kendala bahwa alat bukti yang dimaksud dalam laporan Bawaslu ternyata tidak ada atau mungkin sudah dihilangkan dengan sengaja, sehingga Bawaslu tidak dapat melakukan tindak lanjut terhadap laporan pelanggaran pemilu sebagaimana disampaikan oleh masyarkat.

Tugas utama Bawaslu dalam penanganan pelanggaran pemilu adalah melakukan tindak lanjut terhadap setiap laporan yang diterima dari masyarakat. Tindak lanjut atas laporan tindak pidana pemilu tentu harus ditangani oleh petugas yang memiliki kualifikasi. Bawaslu Kabupaten Simalungun telah berupaya mewujudkan dukungan yang kuat terhadap pelaksanaan pemilu sehingga pemilu benar-benar dapat terlaksana secara jujur dan adil. Kontribusi Bawaslu dengan menetapkan petugas yang berkualifikasi tentu menjadi hal yang sangat baik untuk menciptakan suasana yang baik dalam penyelenggaraan pemilu. Petugas yang menangani pidana pemilu dengan pengetahuan yang luas tentang tindak pidana pemilu yang disertai dengan integritas moral yang tinggi dalam arti tidak dapat disuap tentu akan membuat peserta pemilu menjadi lebih hati-hati dalam setiap tindakan yang tidak melawan hukum sebagaimana dinyatakan dalam UU Pemilu. Pelaksanaan tindak lanjut dengan memeriksa laporan dan memperoleh bukti awal terjadinya tindak pidana pemilu sering kurang didukung oleh laporan yang diterima dari masyarakat. Terdapat juga kemungkinan bahwa semua uraian kejadian sama sekali tidak dapat ditelusuri dengan baik karena adanya upaya dari pihak lain (terlapor) menghapus barang bukti. Selain itu terdapat juga kemungkinan bahwa kejadian yang dilaporkan tidak sesuai dengan fakta di lapangan setelah adanya keterangan dari terlapor.

Pemeriksaan tindak pidana pemilu sering terkendala karena sebagian besar perkara justru melibatkan banyak orang. Disamping itu, banyak barang bukti yang sulit diperoleh, mungkin telah dihilangkan secara sengaja, atau sulit ditemukan karena memang masyarakat secara sengaja menyembunyikan. Kendala lain dalam pemeriksaan juga karena orang-orang melempar tanggungjawab ke pihak lain sehingga keterangan para pihak justru menimbulkan 触 http://mahesainstitute.web.id/ojs2/index.php/jehss 1217

(N) mahesainstitut@gmail.com

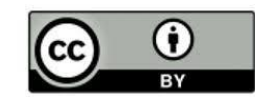


kebingungan. Dalam kondisi demikian, waktu yang sangat terbatas dalam penanganan tindak pidana pemilu tidak memungkinkan untuk menganalisis secara mendalam mengenai siapa sebenarnya yang melakukan pelanggaran, sehingga dapat mendorong Bawaslu menghentikan penyidikan.

Terlapor yang dalam hal ini adalah tersangka tindak pidana pemilu lebih sering tidak bersikap kooperatif selama proses pemeriksaan pelanggaran pidana pemilu. Hal ini tentu menjadi kendala tersendiri mengingat keterbatasan waktu, dimana tersangka dapat secara sengaja tidak bersedia bekerjasama atau bahkan menolak panggilan dari penyidik dengan tujuan agar proses pemeriksaan menjadi sangat lambat. Kuatnya dukungan dari orang-orang lain terhadap tersangka juga menimbulkan kendala, karena dengan dukungan tersebut maka tersangka semakin berani melakukan penolakan untuk bekerjasama dengan Bawaslu. Terdapat anggapan bagi mereka bahwa mengungkapkan dukungan kepada calon tertentu dengan cara apapun bukan merupakan kesalahan. Penghentian pemeriksaan terhadap pelanggaran pemilu yang sering terjadi petugas belum berhasil mengungkap kasus hingga menjadi terang, atau belum berhasil menemukan alat bukti yang kuat, maka Bawaslu akan segera menghentikan pemeriksaan. Hal lain yang dapat menyebabkan diterbitkannya surat penghentian pemeriksaan adalah karena ternyata pelanggaran yang dilaporkan bukan merupakan tindak pidana.

Peran Bawaslu dalam Struktur Sosial Masyarakat, menurut Soerjono Soekanto bahwa peranan juga dapat dikatakan sebagai perilaku yang penting bagi struktur sosial masyarakat. Peran Bawaslu dalam struktur sosial masyarakat adalah untuk memelihara situasi agar tetap kondusif selama penyelenggaraan semua tahapan pemilu. Posisi Bawaslu yang netral dalam arti tidak memihak kepada salah satu calon yang berkompetisi menyebabkan Bawaslu dapat menjadi pencegah yang baik bagi semua pihak jika terjadi perselisihan selama penyelenggaraan pemilu. Peran Bawaslu yang demikian sangat penting mengingat selama pelaksanaan pemilu masyarakat sudah terkotak-kotak berdasarkan aliran, sehingga dapat berpotensi terjadinya konflik yang mengarah pada tindak pidana. Oleh karena itu Bawaslu juga perlu melakukan tindakan pencegahan agar tidak terjadi pelanggaran pidana oleh para pihak yang menjadi peserta dalam pemilu. Dengan demikian jelas dapat dikatakan bahwa Bawaslu berperan dalam struktur sosial masyarakat untuk mencegah terjadinya konflik antar pihak yang berkompetensi dan pendukungnya.

\section{Kendala yang Dihadapi Bawaslu Dalam Penanganan Tindak Pidana Pemilu di Kabupaten Simalungun}

Fakta menunjukkan bahwa selama pelaksanaan pemilu, terdapat banyak pidana pemilu yang dilaporkan oleh masyarakat tetapi tidak dapat diproses hingga ke penuntutan, tetapi justru diberhentikan pada tahap pemeriksaan di Bawaslu karena berbagai alasan tidak ada alat bukti atau dinyatakan bukan merupakan tindak pidana. Semua pihak, baik masyarakat maupun partai politik berharap agar Bawaslu tidak lagi menghentikan perkara pidana pemilu dengan alasan bukan merupakan tindak pidana atau dengan alasan keterbatasan waktu. Keberadaan sentra Gakkumdu pun seoleh tidak membantu mempercepat penyelesaian kasus pidana pemilu karena kurang efektifnya koordinasi antara tiga unsur yang tergabung dalam Gakkumdu, yaitu Bawaslu, kepolisian dan kejaksaan. Bahkan terdapat anggapan dari berbagai pihak bahwa keberadaan sentra Gakkumdu justru menjadi penghambat penegakan hukum pidana pemilu oleh Bawaslu, karena setiap berkas atau laporan yang diterima Bawaslu harus terlebih dahulu dikoordinasikan dalam Gakkumdu sehingga menyebabkan proses hukum menjadi lebih panjang.

Berdasarkan hasil wawancara dengan pihak yang berkompeten di Bawaslu Kabupaten Simalungun, terdapat banyak hal yang menjadi kendala dalam penanganan perkara pidana pemilu, seperti kuatnya perbedaan persepsi antara penegak hukum yang tergabung dalam sentra Gakkumdu, kurangnya komitmen unsur-unsur penegak hukum, jumlah petugas Bawaslu yang terbatas dan lain sebagainya.

1218 http://mahesainstitute.web.id/ojs2/index.php/jehss


Perbedaan Persepsi Dalam Sentra Gakkumdu. Gakkumdu merupakan sentra penanganan terpadu terhadap tindak pidana pemilu, yang dibentuk berdasarkan UU Pemilu, dimana salah satu tujuannya adalah agar semua pidana pemilu dapat diselesaikan dengan cepat. Tetapi kenyataan di lapangan menunjukkan bahwa tujuan tersebut belum dapat tercapai karena banyaknya persepsi yang mungkin timbul secara berbeda di antara unsur penegak hukum. Perbedaan persepsi justru dapat menyebabkan penanganan tindak pidana pemilu menjadi terkendala, karena pada dasarnya ketiga unsur dalam Gakkumdu mempunyai keterlibatan dalam kelanjutan penanganan pidana yang dilaporkan, sehingga tidak ada salah satu unsur pun yang dapat diabaikan. Jika Bawaslu mengabaikan persepsi kepolisian maka besar kemungkinan laporan Bawaslu sulit menindaklanjuti di kepolisian. Artinya bahwa terdapat kemungkinan bahwa rekomendasi dari penyidik kepolisian tidak dapat diterima oleh petugas Bawaslu, sehingga terpaksa mengabaikan rekomendasi yang dimaksud. Adanya perbedaan persepsi menyebabkan Bawaslu mengabaikan rekomendasi dimaksud dan memaksakan laporan tersebut untuk diteruskan ke kepolisian tanpa adanya koordinasi lebih lanjut. Adanya perbedaan persepsi yang kemudian disertai dengan koordinasi yang lemah menyebabkan penanganan perkara menjadi semakin sulit dilaksanakan. Hal ini berarti bahwa untuk mengatasi perbedaan persepsi dalam penanganan tindak pidana pemilu, maka unsur penegak hukum yang tergabung dalam sentra Gakkumdu perlu melakukan koordinasi yang efektif, sehingga dengan demikian segala permasalahan yang dihadapi dapat segera di atasi dengan satu pendapat yang dapat ditindaklanjuti secara bersama.

Barang Bukti Hilang. Kehilangan barang bukti menjadi faktor yang sering terjadi dalam tindak pidana pemilu. Hal ini terjadi karena terdapat kesempatan bagi pihak terkait untuk secara sengaja menghilangkan jejak setelah adanya laporan pihak yang dirugikan ke Bawaslu. Hal ini menunjukkan bahwa para terlapor mempunyai kesempatan yang cukup besar untuk menghapus barang bukti sehingga menyulitkan Bawaslu dalam melakukan pemeriksaan lebih lanjut atas laporan tindak pidana yang disampaikan oleh masyarakat. Setiap perkara tidak dapat dilanjutkan ke pemeriksaan jika barang bukti tidak ada. Pada tindak pidana pemilu banyak pihak yang mungkin berkepentingan menghilangkan barang bukti, terutama tersangka pelaku tindak pidana. Artinya bahwa terdakwa pelanggaran pidana pemilu jarang ditahan oleh kepolisian, karena hal tersebut justru dapat mengganggu keberlangsungan pemilu. Terdakwa akan memanfaatkan kesempatan yang ada untuk secara leluasa menghilangkan barang bukti sebelum laporan ke Bawaslu di teruskan ke penyidik kepolisian. Tetapi sebenarnya terdapat juga banyak perkara dimana masyarakat juga merasa berkepentingan untuk menghilangkan barang bukti. Artinya jelas bahwa kemungkinan hilangnya barang bukti akan semakin besar jika perkara yang dimaksud melibatkan banyak pihak, karena simpatisan yang menjadi pendukung peserta pemilu juga dapat bertindak melindungi calonnya atau kelompoknya dari proses pidana (Zulyadi, 2020).

Tersangka Tidak Kooperatif. Dalam penanganan tindak pidana pemilu sering dijumpai tersangka yang tidak kooperatif terhadap petugas Bawaslu. Padahal dalam setiap pemeriksaan perkara, keterangan terdakwa sangat dibutuhkan. Artinya bahwa tersangka yang tidak menunjukkan niat baik dalam proses penanganan perkara akan berupaya menghindari panggilan petugas Bawaslu dengan menyatakan berbagai alasan. Disamping itu, kalaupun tersangka berhasil dihadirkan, maka tersangka akan memberikan jawaban yang berkelit dan berbelit. Artinya bahwa tersangka juga akan berusaha untuk memberi jawaban yang tidak sesuai dengan fakta yang sesungguhnya terjadi sebagaimana dinyatakan dalam laporan masyarakat, atau justru membuat pembelaan untuk membenarkan tindakan atau pelanggaran pidana yang dilakukan. Tidak jarang juga bahwa tersangka juga mendapat dukungan dari pihak tertentu sehingga lebih berani melawan petugas selama pemeriksaan perkara. Artinya bahwa tersangka dalam tindak pidana pemilu jarang bertindak sendirian sehingga lebih mudah untuk berperilaku tidak kooperatif dengan petugas kepolisian. Adanya pendukung atau intervensi dari pihak tertentu sudah menjadi kebiasaan dalam setiap perkara pidana pemilu, sehingga menyebabkan Bawaslu mengalami kesulitan dalam penanganannya. Oleh karena itu perlu diberi kewenangan

www http://mahesainstitute.web.id/ojs2/index.php/jehss

(N) mahesainstitut@gmail.com 1219

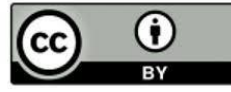

This work is licensed under a Creative Commons Attribution 4. 
kepada Bawaslu untuk melakukan penahanan terhadap tersangka yang tidak kooperatif terhadap tindakan pemeriksaan yang dilakukan oleh Bawaslu.

Petugas Bawaslu yang Terbatas. Kelancaran tugas kepolisian tentu sangat tergantung kepada jumlah petugas yang dapat dikerahkan untuk pelaksanaan tugas. Tetapi masalah yang sering muncul adalah bahwa jumlah petugas selalu tidak sebanding dengan tugas-tugas yang harus dilakukan, sehingga banyak pekerjaan menjadi harus ditunda. Artinya bahwa dengan jumlah petugas Bawaslu yang tidak sebanding dengan banyaknya pekerjaan Bawaslu, maka pelaksanaan tugas harus benar-benar mendahulukan pekerjaan yang paling prioritas. Pekerjaan Bawaslu akan semakin banyak pada saat penyelenggaraan pemilu. Artinya bahwa tugas Bawaslu yang semakin banyak bukan hanya karena meningkatkan laporan pidana pemilu yang harus ditangani, tetapi juga harus melakukan tugas pengawasan terhadap proses penyelenggaraan pemilu. Hal ini juga menjadi penyebab Bawaslu tidak dapat hanya berfokus pada penanganan pelanggaran pidana, karena justru tugas pengawasan di lapangan lebih penting. Artinya bahwa Bawaslu justru harus lebih fokus melakukan tindakan pengawasan terhadap jalannya pemilu, dengan tujuan agar pelanggaran pidana oleh para pihak dapat dicegah. Pengawasan diharapkan dapat mencegah terjadinya tindak pidana, sehingga menjadi prioritas dari Bawaslu dibanding penanganan perkara yang dilaporkan oleh masyarakat.

\section{SIMPULAN}

Peran Bawaslu dalam penanganan tindak pidana pemilu di Kabupaten Simalungun belum sepenuhnya dapat melaksanakan perannya dalam penanganan tindak pidana pemilu. Hal ini dapat dilihat dari selama pelaksanaan pemilu bahwa terdapat banyak pidana pemilu yang dilaporkan oleh masyarakat tetapi tidak dapat diproses hingga ke penuntutan, tetapi justru diberhentikan pada tahap pemeriksaan di Bawaslu karena berbagai alasan tidak ada alat bukti atau dinyatakan bukan merupakan tindak pidana. Semua pihak, baik masyarakat maupun partai politik berharap agar Bawaslu tidak lagi menghentikan perkara pidana pemilu dengan alasan bukan merupakan tindak pidana atau dengan alasan keterbatasan waktu. Kendala yang dihadapi Bawaslu dalam penanganan tindak pidana pemilu adalah: sering terjadi perbedaan persepsi dalam sentra Gakkumdu, adanya kesempatan yang cukup besar untuk menghilangkan barang bukti, tersangka sering tidak kooperatif, serta kurangnya petugas Bawaslu padahal tugas yang harus dilaksanakan terutama pada saat penyelenggaraan pemilu relatif banyak.

\section{DAFTAR PUSTAKA}

Abdurahman, S. (2005). Metode Penelitian Hukum, Jakarta: Bina Cipta.

Ali, A. (2002). Keterpurukan Hukum di Indonesia. Jakarta: Ghalia Indonesia.

Ali, A. (2002). Menguak Tabir Hukum (Suatu Kajian Filosofis dan Sosiologis). Jakarta: Penerbit Toko Gunung Agung.

Ashofa, B. (2000). Metodologi Penelitian Hukum, Jakarta: Rineka Cipta.

Asshiddiqie, J. (2012). Teori Hans Kelsen Tentang Hukum. Jakarta: Konstitusi Press.

Depdikbud, (2005). Kamus Besar Bahasa Indonesia, Balai Pustaka, Jakarta.

Ediwarman. (2016). Monograf Metode Penelitian Hukum (Panduan Penulisan Skripsi, Tesis, dan Disertasi). Medan: Genta Publishing.

Fuady, M. (2003). Dinamika Teori Hukum. Bandung: Citra Aditya Bakti.

Hadi, S. (2000). Metodologi Research, Yogyakarta: Yayasan penerbit Fakultas Psikologi UGM.

Huda, C. (2005). Dari Tiada Perbuatan Tanpa Kesalahan Menuju Kepada Tiada Pertanggungjawaban Pidana Tanpa Kesalahan. Jakarta: Kencana.

Johni, I. (2005). Teori dan Metode Penelitian Hukum Normatif. Malang: Bayu Media Publishing.

Kansil, C.S.T. (2002). Pengantar Ilmu Hukum dan Tata Hukum Indonesia. Jakarta: Balai Pustaka.

Lubis, M. S. (2004). Filsafat Ilmu dan Penelitian, Bandung: Mandar Maju.

Mertokususmo, S. (2005). Mengenal Hukum Suatu Pengantar. Yogyakarta: Liberty.

Rahardjo, S. (2000). Ilmu Hukum. Bandung: Citra Aditya Bakti

Rahardjo, S. (2005). Permasalahan Hukum di Indonesia. Bandung: Alumni

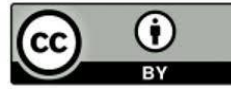


Rawls, J. (2008). Political Liberalism (1993) dalam Materi Kuliah Program Sarjana Hukum Filsafat Hukum Jilid 1. Jakarta: Fakultas Hukum Universitas Indonesia.

Ruslan, R. (2003). Metode Penelitian Public Relation dan Komunikasi. Jakarta: Rajawali Pers.

Salman, O dan Anthon F.S. (2005). Teori Hukum, Mengingat, Mengumpulkan dan Membuka Kembali. Bandung: Refika Aditama.

Sampara, S. (2011). Pengantar Ilmu Hukum, Yogyakarta: Total Media.

Soekanto, S dan Mamudji, S. (1995). Penelitian Hukum Normatif Suatu Tinjauan Singkat, Raja Jakarta: Grafindo Persada.

Soekanto, S. (2001). Pengantar Penelitian Hukum. Jakarta.

Utrecht. (2002). Pengantar Hukum Administrasi Negara Indonesia. Jakarta: Ichtiar.

Waluyo, B. (1993). Metode Penelitian Hukum. Semarang: Ghalia Indonesia.

Zulyadi, R. (2020). Kerangka Teori Dalam Penelitian Hukum. Medan: Enam Media.

Perundang-undangan:

Kitab Undang-Undang Hukum Pidana (KUHAP)

Undang-Undang Nomor 2 Tahun 2002 Tentang Kepolisian Negara Republik Indonesia

Undang-Undang No. 7 Tahun 2017 Tentang Pemilihan Umum.

Website:

Aunurrohim, Mohamad, "Keadilan, Kepastian, dan Kemanfaatan Hukum di Indonesia" dikutip dari http://www.academia.edu.com diakses 17 September 2020.

www.purnama-bgp.blogspot.com

www.Bawaslu.go.id/pdf

https://medanmerdeka.com/pemilu/Bawaslu-simalungun-bidik-oknum-pejabat-dan-kades, diakses pada tanggal 20 November 2020 .

http://indofakta.com/html/news_16069.html3, diakses pada tanggal 20 November 2020.

https://www.mistar.id/simalungun/camat-gunung-malela-akhirnya-dilapor-ke-Bawaslu-simalungun, diakses pada tanggal 20 November 2020.

https://www.mistar.id/simalungun/pp-simalungun-terima-banyak-pengaduan-soal-pelanggaranpilkada-yang-dilakukan-asn, diakses pada tanggal 20 November 2020. 